\title{
Problems and Prospects of Commodity Futures Broking: A Depositary Participants Survey in East and West Godavari Districts of Andhra Pradesh INDIA
}

\author{
Dr V.V.Ratnaji Rao Chowdary, \\ Associate Professor PGDepartment of Commerce and Management Studies VSMCollege Ramachandrapuram- \\ 533255 INDIA
}

\begin{abstract}
The latest buzzword in the financial literature is "Derivatives" the birth of which is traced back to 1973 when Fisher and Myron Scholes published an article on European Call Option valuation. In the last decade, many emerging and transition economies have started introducing derivative contracts. As was the case when commodity futures were first introduced on the Chicago Board of Trade (CBOT) in 1865, policy makers and regulators in these markets were concerned about the impact of futures on the underlying cash market. One of the reasons for this concern was the belief that futures trading attract speculators, who can destabilize spot prices.

"The safety and economy in communications, which enable a deficiency in one place to be, supplied from the surplus of another render the fluctuations of prices much less extreme than formerly. This effect is much promoted by the existence of speculative merchant. Speculators, therefore, have a highly useful office in the economy of society". Since, futures encourage speculation, the debate on the impact of speculators intensified when futures contracts were first introduced for trading; beginning with commodity futures and moving on to financial futures and recently futures on weather and electricity. However, this traditional favorable view towards the economic benefits of speculative activity has not always been acceptable to regulators.
\end{abstract}

\section{Introduction}

The origin of derivatives can be traced back to the need of farmers to protect themselves against fluctuations in the price of their crop. From the time of slowing to the time of crop harvest, farmers would face price uncertainty through the use of simple derivative products. It was possible for the farmer to partially or fully transfer price risks by locking-in asset prices. These were simple constraints developed to meet the needs of farmers and were basically a means of reducing risk. On other hand, a merchant with an ongoing requirement of grains too would face a price risk-that of having to pay exorbitant prices during dearth, although favorable prices could be obtained during period of oversupply. Under such circumstances, it clearly made sense for the farmer and the merchant to come together and enter into a contract whereby the price of the grain to be delivered in September could be decided earlier. What they would them negotiate happened to be a futures type contract. This would enable both parties to eliminate the price risk.

In 1848, the Chicago Board of Trade (CBOT) was established to bring farmers and merchants together. A group of traders got together and created the 'to-arrive' contract that permitted farmers to lock into price upfront and deliver the grain later. These to arrive contracts proved useful as a device for hedging and speculation on anticipate price changes. These were eventually standardized and in 1925 the first futures clearing house came into existence. To-day derivative contracts exist on a variety of commodities such as Cotton, Corn, Sugar, Pepper, Jeera, Turmeric, Silver and Gold etc.,

\section{Commodity Derivative Markets in India:}

Commodity futures markets have a long history in India. Cotton was the first commodity to attract futures trading in the country leading to the setting up of the Bombay Cotton Trade Association Ltd., in 1875 subsequently, many exchanges came up in different parts of the country for futures trading in various commodities. After independence, with the subject of 'stock exchanges list, responsibility for regulation of commodity futures markets developed on government of India. A Bill on forward contracts was referred to an expert committee headed by Prof. A.D.Shroff and select committees of two successive parliaments and finally in December 1952 Forward Contracts (Regulation) Act, 1952 was enacted. The year 2003 is a land mark in the history of commodity futures market witnessing the establishment and recognition of three new national exchanges (National Commodity and Derivatives Exchanges of India Ltd (NCDEX), Multi Commodity Exchange of India Ltd., (MCX), National Multi Commodity Exchange of India Ltd., (NMCE) with online trading and professional management. 


\section{Evolution of Commodity Exchanges:}

Commodity exchanges are defined as centre where futures trade is organized. Most of the commodity exchanges, which exist today, have their origin in the late $19^{\text {th }}$ and earlier $20^{\text {th }}$ century. The emergence of the derivatives markets as the effective risk management tools in 1970s and 1980s has resulted in the rapid creation of new commodity exchanges and expansion of the existing ones.

\section{Objectives:}

$>$ To study the problems confronted by the commodity derivative brokers in Andhra Pradesh in general and Godavari Districts particularly.

$>$ To study the strengths and opportunities of commodity derivative broking Godavari Districts.

$>$ To make suitable suggestions on the basis of the findings of the study

\section{Methodology:}

This study is based on both Primary and Secondary data. Primary data is obtained from 30 Respondents (including Department Heads, Branch Heads and Dealers) from three commodity broking companies' viz. Share khan, Motilal Oswal and Religare Commodities in East and West Godavari Districts in Andhra Pradesh through survey. Secondary data is collected from Journals, Magazines and related websites. The study is designed as an exploratory is based on survey method.

\section{Profile of Respondents:}

Most of the respondents are in the age group of 31 to 40 Years (53.33\%) and 20 to 30 Years (46.67\%) among the respondents, the highest gender group is Male which stands at $60.4 \%$ compared to female at $39.6 \%$ and Majority of the respondents are Graduates 64.2\%compared to Post Graduates at 35.8\%.

Table No.1

Responds from Main Income of Commodity Brokers

\begin{tabular}{|c|c|c|c|c|c|c|}
\hline $\begin{array}{c}\text { Source of } \\
\text { Income }\end{array}$ & $\begin{array}{c}\text { Rank } \\
1\end{array}$ & $\begin{array}{c}\text { Rank } \\
2 \\
\end{array}$ & $\begin{array}{c}\text { Rank } \\
\mathbf{3} \\
\end{array}$ & $\begin{array}{c}\text { Rank } \\
4 \\
\end{array}$ & Total Score & $\begin{array}{l}\text { Overall } \\
\text { Weight }\end{array}$ \\
\hline Speculation & 26 & 4 & 0 & 0 & 116 & 1 \\
\hline Physical Delivery & 4 & 16 & 6 & 4 & 80 & 2 \\
\hline Arbitrage & 0 & 2 & 8 & 20 & 42 & 4 \\
\hline Hedging & 0 & 8 & 16 & 6 & 62 & 3 \\
\hline
\end{tabular}

Source: Compiled from field survey

Table 1 illustrates that main income for commodity brokers is from speculation become it is ranked 1. Physical delivery is the second source. Hedging and arbitrage is in third and forth position respectively.

Table No.2

Responds regarding problems faced by commodity brokers+

\begin{tabular}{|l|c|c|}
\hline Items & $\begin{array}{c}\text { No. of } \\
\text { Respondents }\end{array}$ & Percentage \\
\hline Agree & 28 & 93.33 \\
\hline Disagree & 2 & 6.67 \\
\hline Total & $\mathbf{3 0}$ & $\mathbf{1 0 0 . 0 0}$ \\
\hline
\end{tabular}

Source: Compiled from field survey

From the table 2 it can understand that 93.33 Percentage of the respondents agree that the commodity brokers are facing problems the remaining 6.67 Percentage were Disagree.

Table No.3

Responds regarding various problems

\begin{tabular}{|l|c|c|c|c|c|c|c|}
\hline Problems & Rank & Rank & Rank & Rank & Rank & $\begin{array}{c}\text { Total } \\
\text { Score }\end{array}$ & $\begin{array}{c}\text { Overall } \\
\text { Weight }\end{array}$ \\
\hline Competition & 24 & 6 & 0 & 0 & 0 & $\mathbf{1 4 4}$ & $\mathbf{1}$ \\
\hline Regulations & 0 & 0 & 0 & 0 & 30 & $\mathbf{3 0}$ & $\mathbf{5}$ \\
\hline Low Brokerage & 4 & 16 & 8 & 2 & 0 & $\mathbf{1 1 2}$ & $\mathbf{2}$ \\
\hline $\begin{array}{l}\text { Exchange Control } \\
\text { Over Margins }\end{array}$ & 0 & 2 & 18 & 10 & 0 & $\mathbf{8 2}$ & $\mathbf{3}$ \\
\hline $\begin{array}{l}\text { Lack of Qualifies } \\
\text { Manpower }\end{array}$ & 0 & 6 & 6 & 18 & 0 & 78 & 4 \\
\hline
\end{tabular}

Source: Compiled from field survey 
From the Table 3 it was found that the main problem faced by commodity broking service is competition. Low rate of brokerage is also a big problem faced by the industry. Commodity exchanges make several controls over brokers like margin percentage hike. It will affect the business. Inadequacy of qualified manpower and regulations from FMC (Forward Market Commission) are ranked third and forth.

Table No.4

Responds regarding Opportunities

\begin{tabular}{|c|c|c|c|c|c|c|}
\hline Opportunities & $\begin{array}{c}\text { Rank } \\
1\end{array}$ & $\begin{array}{c}\text { Rank } \\
2\end{array}$ & $\begin{array}{c}\text { Rank } \\
3\end{array}$ & $\begin{array}{c}\text { Rank } \\
4\end{array}$ & $\begin{array}{l}\text { Total } \\
\text { Score }\end{array}$ & $\begin{array}{l}\text { Overall } \\
\text { Weight }\end{array}$ \\
\hline FII Participation & 16 & 48 & 12 & 4 & 80 & 2 \\
\hline Participation from MFs & 16 & 27 & 18 & 8 & 69 & 3 \\
\hline Bank Participation & 8 & 12 & 14 & 17 & 51 & 4 \\
\hline Introduction of Options & 80 & 18 & 6 & 1 & 105 & 1 \\
\hline
\end{tabular}

Source: Compiled from field survey

From the table 4, it can conclude that majority of the respondents ranked introduction of options is the number one opportunity in front of commodity brokers. It will increase the volume of trading and it will help to reduce risk through hedging. Second rank is for FIIs participation. If FIIs are allowed to enter into this market like stock market, it will also help to increase the volume and liquidity of commodity futures market as participants it will make a big difference in this market.

\section{Major Findings of the study:}

$>$ Most of the respondents are in the age group of 31 to $40(53.33 \%)$ and 20 to $30(46.67 \%)$

$>$ Among the respondents the highest gender group is male which stands at $60.4 \%$ compared to female at $39.6 \%$

$>$ On the ethnicity, $64.2 \%$ of the respondents are graduates compared to post graduates at $35.8 \%$

$>$ Table 1 illustrates that the main income for commodity brokers is from speculation because it is ranked first physical delivery of commodities from exchanges through commodity brokers is the second ranked income

$>$ From Table $2.93 .33 \%$ of the respondents agree that commodity brokers are facing problems.

$>$ From table 3 data we can see that the main problem faced by commodity broking service is competition. Low rate of brokerage is also a big problem faced by the industry.

$>$ From Table 4, it can conclude the majority of the respondent's ranked introduction of options is the number one opportunity in front of commodity brokers. Second rank is for FIIs participation

\section{Conclusion and Recommendations:}

The objective of the study was to find the problems faced by commodity brokers and the opportunities ahead in Andhra Pradesh with reference to East and West Godavari Districts because District head quarters and most of the commodity brokers have their branches. Overall the study indicated that 93.33 percentage of the respondents agreed that they are facing problems. The major problems faced by them are completion and low brokerage rate. From the study the four major opportunities they highlighted are introduction of options, FIIs participation, Banks participation and participation of Mutual Funds. In order to get more volumes and increase the liquidity of the market it is essential to introduce options in commodity derivative market in India. This will help the commodity brokers to increase their Busines and ultimately lead to motivation.

[1]. NCFM (Commodity Market Module)

References:

[2]. Report of the Working group on commodity futures, Department of Banking Operations and development (Mumbai 2005)

[3]. Economic times

[4]. NICR Learning portal

[5]. N.D.Vohra, B.R.Bagri, Futures, Options and Other Derivatives, Tata McGraw Hill

[6]. Gupta, S.L., Financial Derivatives, Prentice Hall of India.

[7]. J.C.Hull, Futures, Options and Other Derivatives, Prentice Hall of India. 